\title{
Diamond Grinding the Ceramic Balls from Silicon Carbide
}

Sokhan' S. V.*, Maystrenko A.L., Kulich V. H., Sorochenko V. H., Voznyy V. V., Gamaniuk M.P., Zubaniev Ye. M. Bakul Institute for Superhard Materials of NAS of Ukraine, 2 Avtozavodska St., Kyiv, 04074, Ukraine

\section{Article info:}

Paper received:

The final version of the paper received:

Paper accepted online:
November 11, 2017

March 12, 2018

March 20, 2018
*Corresponding Author's Address:

svsokh@ukr.net

\begin{abstract}
The influence of the machining regime was experimentally investigated on the output indexes of the diamond grinding the ceramic balls from silicon carbide, such as the rate of the material removal and the rate of changing (decreasing or increasing) the deviation from sphericity of the ball's surface. To distinguish a particle of these indexes as caused by the actual influence of the machining regime was applied a method of graphical approximation of the time-varying ball's diameter and deviation from sphericity. The separated particles of the process indexes can vary both as growing and as decreasing depending on the values of the parameters of the machining regime, such as: the discrete feeding of the diamond wheel to the cutting, the time of grinding between feedings of the wheel and the rotation speed of the table with the balls. For further determining the influence of the machining regime was applied a method of a complete factor-type experiment of type $2^{3}$, in which the factors of the above parameters were specified. As a result, the most effective way to reduce the deviation from the sphericity of the ball's surface is to combine these parameters.
\end{abstract}

Keywords: ceramic balls from silicon carbide, diamond grinding, rate of the material removal, rate of changing the ball's shape, machining regime, discrete feeding of the diamond wheel to the cutting, time of grinding between feedings of the wheel, rotation speed of the table.

\section{Introduction}

Many branches of industry exploit a large number of rolling bearings, pumps, hydromotors and other mechanisms, the resource and reliability of which depend on the efficiency and quality of parts such as "ball". Now balls are mainly made of steel and they are relatively quickly failured in conditions of high loads, temperatures, as well as intense abrasive, corrosion, chemical and other types of wear. Replacing steel balls on ceramic in many cases allows you to achieve higher performance and extend the range of functionality of the devices in which they are used. Thus, in hybrid ball bearings combination of rolling ceramic bodies and high quality of surface of steel rings (Figure 1) gives the advantages for longer service life and better performance at high speeds.
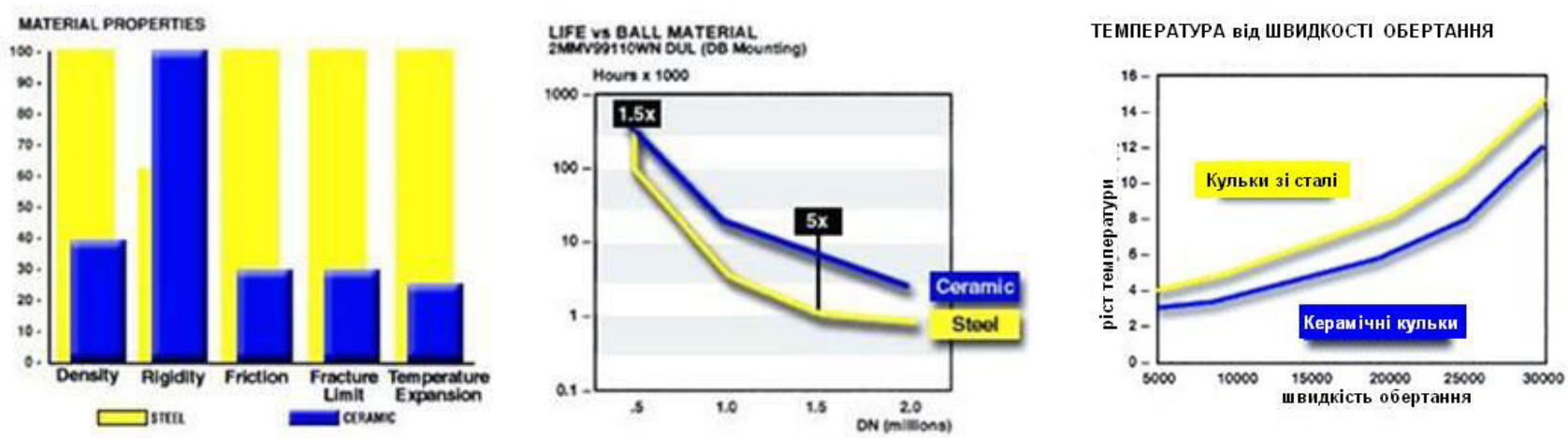

Figure 1 - Comparison of characteristics of hybrid and steel ball bearings [1] 


\section{Literature Review}

In the 1990s, the leading organizations of the National Academy of Sciences of Ukraine contributed to the creation of effective ceramic and composite materials based on boron and silicon carbides, as well as technologies for manufacturing precision products of the "ball" type [2, 3] that work in difficult operating conditions. Firstly, it concerns materials based on boron carbide - it is the third according to the hardness of a material after diamond and cubic boron nitride, and one of the most inert chemical compounds. It has high hardness, durability and unique wear resistance under acting aggressive environments and abrasive wear.

An important incentive for the development of modern technical ceramics is the desire to develop a gas turbine engine with a high efficiency for the aerospace industry. The conditions of the bearings of the main shaft of such engines - the shaft speed more than $30000 \mathrm{rpm}$ and temperatures above $650{ }^{\circ} \mathrm{C}$. At temperatures above $1100{ }^{\circ} \mathrm{C}$, only ceramic materials are used because their higher hardness than those of bearing steel or even cobalt alloys and high-speed steels with high content of tungsten.

The most difficult in the manufacture of any ball bearings is the abrasive machining the balls. The operational properties of the bearings depend, first, on the perfomance of their working surfaces, such as the precision of machining, roughness and microstructure. The group abrasive finishing of balls between rotating discs is the most versatile operation of making balls and up to this time attracts the attention of researchers [4-6]. At diamond grinding or finishing ceramic balls are rolled along the tracks of the lower disk without their mixing unlike elevator abrasive machining the steel balls in mass production when their mixing. Becouse of it is limited the number of simultaneously machined ceramic balls by their placement on the tracks of the lower disk and to achive high accuracy the ball's shape is difficult.

\section{Research Methodology}

\subsection{Features of surface layer forming in ceramic products from silicon carbide by diamond grinding}

As well as for any brittle nonmetallic material, the diamond grinding of ceramic products, in particular from silicon carbide, is radically different from the abrasive grinding of metals [7-9]. When the diamond grinding brittle nonmetallic materials, there are an elastic-plastic deformation without breaking, as well dispersing the machining allowance at plastic deformation and brittle breaking the material with particle chipping. The probability of one or another mechanism of the destruction of the machining allowance is determined both by the physical and mechanical properties of the material and the load on the diamond grain (depending on the machining regime). A characteristic result of material removing during diamond grinding are lateral breakaways and clus- ter breaking on the surface layer, which are watched in the form of cells of destruction, which most influence the formation of the surface roughness [10]. In theoretical study of interaction between grains of abrasive powder and machined surface from brittle nonmetallic materials is used the cluster model of formation and removal of slime particles $[11,12]$.

The nature of the destruction of such brittle nonmetallic material, which is a silicon carbide, depends mainly on the magnitude of the normal force on diamond grains. When the normal force achieves own critical value, which is required for the formation of lateral cracks, the destruction results by scraping. The critical force that forms lateral cracks is determined by the dependence

$$
P_{c r}=k_{p} \cdot \frac{K_{1 C}^{4}}{H_{\mu}^{3}},
$$

where $k_{p}$ - constant coefficient; $K_{1 C}-$ stress intensity factor of the first type (critical intensity of cracking); $H_{\mu}-$ microhardness [13].

Proceeding from the physical and mechanical properties of the materials under consideration (Table 1), the critical force that forms lateral cracks in the surface layer of the hot-pressed silicon nitride is more than 2.3 times for the reaction-bonded silicon carbide. Therefore, when grinding carbide ceramics, the critical cross-sectional area of the material on the diamond grain [10], which takes place the breakaways, is smaller and, accordingly, several times smaller than for nitride ceramics is required for the cutting depth to appear the breakaways.

On the other hand, the critical size of the median fracture, in which it begins to develop in a steady manner during infusion, is inversely proportional to the square of the material fragility index

$$
l_{M}=\frac{k_{M}}{\left(H_{\mu} / K_{1 C}\right)^{2}},
$$

where $k_{M}-$ constant coefficient [13]. Experimentally proved during diamond machining [10] that the magnitude of the maximum half-length of defects in the surface layer of ceramics is linearly dependent on the critical size of the median fracture during the indentation, in which the crack develops. If the the index of fragility of the material is smaller, and consequently, the magnitude of the critical median fracture is greater when indenting, than the higher the value should be expected both the half-length of the maximum crack from the machining, and the depth of the cracked layer. Therefore, based on the data of the Table 1 under the same conditions of grinding, the breakaways on the machined surface of carbide ceramics should be larger, and the depth of the cracked layer - on the contrary, less than that of the surface of the nitride ceramics. At the same time, it should be noted that the comparative analysis taken into account only the physical and mechanical properties of the materials, but not the actual conditions of diamond grinding 
(machining regime, etc.), which determine the depth of the cracked layer.

Taking into account the predisposition of the $\mathrm{SiC}$ ceramics to cracking, as well as the peculiarities of the diamond grinding ceramic balls from silicon carbide, the purpose of the work was to determine the influence of the machining regime on the output indixes, such as the rate rate of the material removal and the rate of changing the deviation from sphericity.

Table 1 - Results of treatment of the wall thickness experimental measurements in cross sections of a tube

\begin{tabular}{|l|c|c|}
\hline \multicolumn{1}{|c|}{ Indicator } & $\begin{array}{c}\mathrm{Si}_{3} \mathrm{~N}_{4} \text {-ceramics } \\
\text { (hot-pressed) [10] }\end{array}$ & $\begin{array}{c}\text { SiC-ceramics } \\
\text { (reaction- } \\
\text { bonded) [14] }\end{array}$ \\
\hline Density, g/sm ${ }^{3}$ & 3.1 & 3.12 \\
\hline Young's module, $\mathrm{GPa}$ & 310 & 413 \\
\hline Microhardness $H_{\mu}, \mathrm{GPa}$ & 13.9 & 20 \\
\hline Bending strength $\sigma_{3}, \mathrm{MPa}$ & 690 & 370 \\
\hline Index of fragility $H_{\mu} / K_{1 C}$ & 3.23 & 4.35 \\
\hline Critical stress intensity factor of the first type $K_{1 C}, \mathrm{MPa} / \mathrm{m}^{0.5}$ & 4.3 & 4.6 \\
\hline
\end{tabular}

\subsection{Experimental research}

Investigation of the influence of the machining regime on the output indixes of diamond grinding ceramic balls from reaction-bonded silicon carbide carried out on a modernized ball-grinding machine VS-D204M (Figure 2) with the technological device for a placement of the balls on its desktop, the scheme of which shown in Fig. 3

As can see from the machining scheme shown in Figure 3, the device separates the kinematic chains on that, which realizes directly shaping, and on that, which realizes portable movements from the chain for the grinding process. Thanks to the device machining balls is carryed out at optimal grinding speeds of $25-30 \mathrm{~m} / \mathrm{s}$ and the speed of moving balls of $0.15-0.30 \mathrm{~m} / \mathrm{s}$. In the experiments, a diamond grinding wheel of 6A2T form was applied with diamonds of grade AS32 with a grain size $250 / 200$ of relative concentration of 100 . The number of balls in the batch, which was simultaneously machined, was eight pcs.

The output indixes were the rate of the material removal $v_{d}=\Delta d / t$ (rate of reducing ball's diameter) and the rate of changing of the ball shape $v_{\delta}=\Delta \delta / t$ (rate of decrease or increase of deviation from sphericity). There was studied the influence of such regime parameters as discrete feeding of the wheel to the cutting sw, the time of grinding between feedings to and the rotation speed of the table with balls st. The output indixes of machining process were counted after direct measurement on each ball of its diameter and deviation from sphericity before and after each experiment.

Measurement of the diameter of the ball was carried out on a longitudinal vertical type of IZV-2 with division value of measurement scale of $1 \mu \mathrm{m}$. The diameter of the ball was measured in 3 mutually perpendicular directions, with the direction chosen arbitrarily. On the basis of measurements, it was calculated the average diameter of each ball and the average diameter of the balls in the batch before and after each experiment.

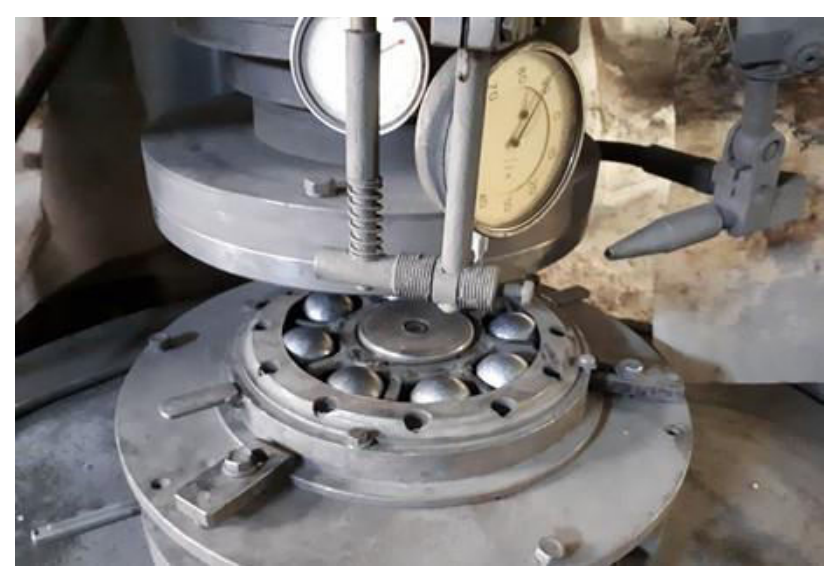

Figure 2 - The location of ceramic balls in the device on the ball-grinding machine VS-D204M

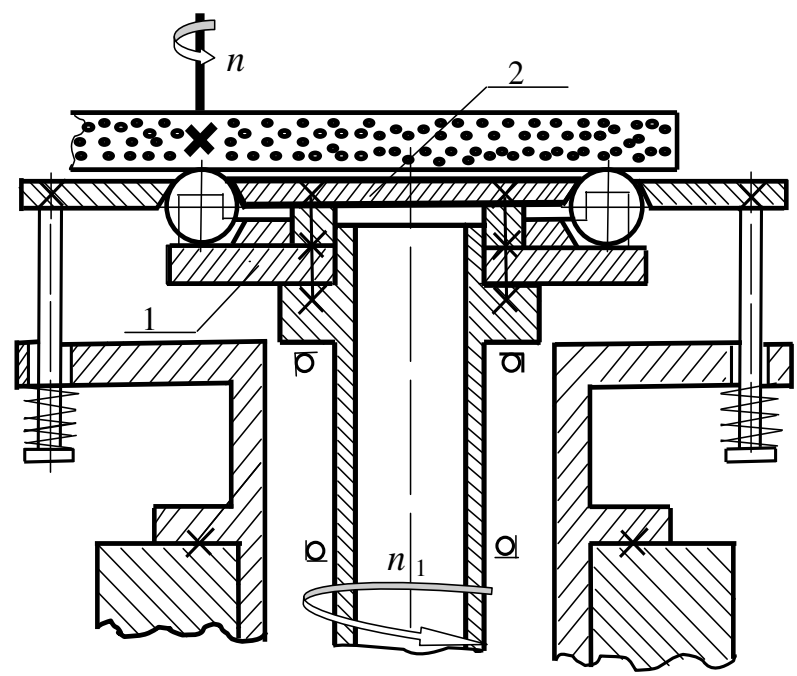

Figure 3 - Scheme of grinding of ceramic balls in a device with kinematically connected upper and lower disks 
Measurement of deviation from the sphericity of ball surface was carried out by the indicating gage type MIG-1 with division value of measurement scale of $1 \mu \mathrm{m}$. The indicating gage was fixed on a magnetic tripod. The measured ball was located on the base ring with the outer and inner chambers, in order to get as close as possible to the conditions of contact of the ball and the ring around the circle. The base diameter of the ring was chosen as the diameter of the circle inscribed in an equilateral triangle, which in turn is inscribed in a circle with a maximum ball diameter. As a result of measurements when turning the ball on the base ring found the maximum and minimum value of deviation from the sphericity of the ball surface. On the basis of measurements, the average deviation on each ball was calculated as well as the average deviation of the ball surface in the batch before and after each experiment.

Further, the actual influence was separated out of the machining regime in the indicators of diamond grinding of balls (the rate of reducing ball's diameter and the rate of changing ball's shape), which occurs on the background of the general tendency to monotonically nonlinear decline of these indexes from its original value to the level of the minimum possible value for this grinding scheme and this processing time. This tendency is due to our view, firstly, by the gradual transition from the machining of the weakened surface layer as a two-layer combination of relief and cracked layers to the machining of the material itself and the associated increase in the physical and mechanical properties of the material being processed, which leads to a decrease in the circumferential feed of grinding (i.e. speed of run-off on a wheel of removed material) due to the self-regulation of the angu- lar velocity of ball's rolling under the action of frictioncoupling and cutting forces. Secondly, this trend is due to the simultaneous monotonous increase in the proportion of the machining time of the main material in the overall time of the experiment.

To separate out the influence of the machining regime, there was used method of graphical approximation using a monotonous continuous time function of the mean values of the ball's diameter $d_{m}$ and the deviation from the sphericity of the ball's surface $\delta_{m}$ both before and after each experiment. The effect of the treatment mode was considered to be the difference between the mean $d_{m}$ or $\delta_{m}$ after each experiment and the value of the approximation function at this point of the total processing time. The rate of reducing ball's diameter and the rate of change in the shape of their surface (in general, after approximation and under the action of the machining regime itself) were counted in $\mu \mathrm{m} / \mathrm{min}$ after each experiment, taking into account the time of the experiment.

As a method for further determining the influence of machining regime on the indexes of diamond grinding ceramic balls, a complete factor experiment of type $2^{3}$ was chose, since there was no quantitative assessment of the degree of influence of factors. The experiment plan envisaged the variation of all factors on two levels: the discrete feeding of the wheel to the cutting $s_{w}-50$ and $70 \mu \mathrm{m}$, time of grinding between feedings to 10 and $20 \mathrm{~min}$, the rotation speed of the table with balls $s_{t}-$ 35 and $85 \mathrm{rpm}$. The time for each experiment was 40 minutes. The matrix of experiment planning is given in Table 2. It takes into account the interaction of factors.

Table 2 - Experiment planning matrix type $2^{3}$ in relative values

\begin{tabular}{|c|c|c|c|c|c|c|c|c|c|}
\hline Exp. no. & $x_{1}$ & $x_{2}$ & $x_{3}$ & $x_{1} x_{2}$ & $x_{1} x_{3}$ & $x_{2} x_{3}$ & $x_{1} x_{2} x_{3}$ & Alphanumeric characters & $y$ \\
\hline 1 & -1 & -1 & -1 & +1 & +1 & +1 & -1 & $(1)$ & $y_{1}$ \\
\hline 2 & +1 & -1 & -1 & -1 & -1 & +1 & +1 & $a$ & $y_{2}$ \\
\hline 3 & -1 & +1 & -1 & -1 & +1 & -1 & +1 & $b$ & $y_{3}$ \\
\hline 4 & +1 & +1 & -1 & +1 & -1 & -1 & -1 & $c$ & $y_{4}$ \\
\hline 5 & -1 & -1 & +1 & +1 & -1 & -1 & +1 & $a b$ & $y_{5}$ \\
\hline 6 & +1 & -1 & +1 & -1 & +1 & -1 & -1 & $a c$ & $y_{6}$ \\
\hline 7 & -1 & +1 & +1 & -1 & -1 & +1 & -1 & $b c$ & $y_{7}$ \\
\hline 8 & +1 & +1 & +1 & +1 & +1 & +1 & +1 & $a b c$ & $y_{8}$ \\
\hline
\end{tabular}

Based on the results of experiments, linear models of the output variables were constructed, taking into account the interaction of factors in the form

$$
y=b_{0}+b_{1} x_{1}+\ldots+b_{k} x_{k}+b_{k+1} x_{1} x_{2}+\ldots+b_{2 k} x_{k-1} x_{k},
$$

in which coefficients of the linear model are calculated by the formulas:

$$
\begin{aligned}
& b_{\mathrm{j}}=\frac{1}{n} \sum_{i=1}^{n} X_{j i} Y_{i}, j=\overline{0, k} \\
& b_{j+k}=\frac{1}{n} \sum_{i=1}^{n}\left[X_{j i} X_{(j+1) i}+X_{j i} X_{(j+2) i}\right] Y_{i}, j=\overline{1, k} .
\end{aligned}
$$

\section{Results}

According to the recommendations of statistical data processing [15], in the calculation of the average values of measured parameters - the ball's diameter and the deviation from the sphericity of ball's surface, the results were not found with a confidence probability of 0.95 , which are sharply distinguished among others. The validation of samples dispersion according to the Cochran criterion showed that they are homogeneous - in Table 3 the results are given after calculating the samples dispersion in the measurements of 8 balls in each of the 8 experiments, as well as before the start of measurements, and in addition the results of their verification for homogeneity according to the Cochran criteria. If $G \leq G_{t a b l}$, then the samples dispersions are homogeneous. 
Table 3. Samples dispersion in 8 measurements for each of the 8 experiments, and before the start of measurements, their verification for homogeneity according to the Cochran criterion

\begin{tabular}{|c|c|c|c|c|c|c|c|c|c|c|c|}
\hline \multirow{2}{*}{ 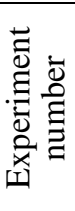 } & \multicolumn{8}{|c|}{ Dispersion of measurements on 8 balls } & \multirow{2}{*}{$\begin{array}{c}\text { Sample's } \\
\text { dispersion } \\
\text { in the } \\
\text { experi- } \\
\text { ment } S_{i}^{2}\end{array}$} & \multirow{2}{*}{$\begin{array}{c}G=S_{\max }{ }^{2} / \\
\Sigma S_{i}^{2}\end{array}$} & \multirow{2}{*}{$\begin{array}{c}G_{0,95 \mathrm{tabl}} \\
\text { at } k= \\
8, v=1\end{array}$} \\
\hline & 1 & 2 & 3 & 4 & 5 & 6 & 7 & 8 & & & \\
\hline \multicolumn{12}{|c|}{ Measuring the ball's diameter, $\mu \mathrm{m}^{2}$} \\
\hline init. & 0.07877 & 0.01702 & 0.00977 & 0.12377 & 0.00002 & 0.14102 & 0.02627 & 0.00827 & 0.000058 & 0.3483 & 0.6798 \\
\hline 1 & 0.14400 & 0.02500 & 0.04900 & 0.25600 & 0.19600 & 0.03600 & 0.00900 & 0.02500 & 0.000106 & 0.3460 & 0.6798 \\
\hline 2 & 0.00306 & 0.03906 & 0.01406 & 0.06006 & 0.03306 & 0.00006 & 0.01056 & 0.08556 & 0.000035 & 0.3485 & 0.6798 \\
\hline 3 & 0.04727 & 0.17227 & 0.11827 & 0.00977 & 0.22877 & 0.01502 & 0.08327 & 0.35627 & 0.000147 & 0.3456 & 0.6798 \\
\hline 4 & 0.00977 & 0.08327 & 0.00127 & 0.01702 & 0.00827 & 0.01702 & 0.19252 & 0.02377 & 0.000050 & 0.5456 & 0.6798 \\
\hline 5 & 0.05077 & 0.00352 & 0.02377 & 0.00827 & 0.05077 & 0.00077 & 0.00077 & 0.00827 & 0.000021 & 0.0052 & 0.6798 \\
\hline 6 & 0.01502 & 0.11827 & 0.06202 & 0.03752 & 0.12377 & 0.02627 & 0.06202 & 0.06602 & 0.000073 & 0.0514 & 0.6798 \\
\hline 7 & 0.00002 & 0.02627 & 0.00002 & 0.06602 & 0.00827 & 0.00977 & 0.03752 & 0.39502 & 0.000078 & 0.0180 & 0.6798 \\
\hline 8 & 0.00025 & 0.04225 & 0.01225 & 0.00225 & 0.05625 & 0.00025 & 0.00225 & 0.00625 & 0.000017 & 0.0020 & 0.6798 \\
\hline \multicolumn{12}{|c|}{ Measuring deviation from sphericity, $\mu \mathrm{m}^{2}$} \\
\hline init. & 63.57 & 24.30 & 58.14 & 0.23 & 14.37 & 3.12 & 0.14 & 27.18 & 27.29 & 0.3327 & 0.6798 \\
\hline 1 & 1.00 & 30.84 & 61.19 & 22.02 & 123.64 & 0.04 & 6.03 & 54.93 & 42.81 & 0.4126 & 0.6798 \\
\hline 2 & 11.50 & 0.52 & 3.75 & 3.28 & 0.01 & 16.58 & 0.35 & 2.78 & 5.54 & 0.4276 & 0.6798 \\
\hline 3 & 0.01 & 8.33 & 1.11 & 0.80 & 1.35 & 0.61 & 4.39 & 25.84 & 6.06 & 0.6090 & 0.6798 \\
\hline 4 & 0.12 & 0.28 & 2.84 & 6.85 & 1.83 & 22.88 & 6.52 & 0.86 & 6.02 & 0.5426 & 0.6798 \\
\hline 5 & 24.96 & 4.90 & 2.92 & 16.38 & 13.92 & 0.36 & 5.93 & 1.16 & 10.08 & 0.3539 & 0.6798 \\
\hline 6 & 0.76 & 2.88 & 0.66 & 11.58 & 0.21 & 10.28 & 0.01 & 17.26 & 62.35 & 0.3955 & 0.6798 \\
\hline 7 & 2.84 & 3.51 & 0.64 & 9.07 & 2.58 & 6.85 & 2.38 & 2.58 & 4.35 & 0.2981 & 0.6798 \\
\hline 8 & 1.41 & 0.09 & 1.26 & 7.66 & 9.31 & 1.81 & 0.55 & 2.97 & 3.58 & 0.3717 & 0.6798 \\
\hline
\end{tabular}

Since the output variables of the grinding process are estimated values based on each time on the measurement of the geometric indices mentioned in the research methodology, the dispersion of reproduction in each experiment was counted as the average samples dispersion in the current and previous experiments:

$$
S_{r e p r}^{2}=\frac{1}{2}\left(S_{i}^{2}+S_{i-1}^{2}\right)
$$

and the weighted average variance in the 8 experiments is

$$
S_{r e p r}^{2}=\frac{1}{N} \sum_{i=1}^{N} S_{r e p r i}^{2}
$$

at degrees of freedom $f_{\text {repr }}=N(m-1)$, where $N$ - number of experiments, $m$ - the number of measurements in each experiment.

The dispersion of the reproduction is calculated: for the average diameter of the balls $-6.8452 \cdot 10^{-2}$ and for deviation from sphericity -12.0663 .

To determine the component of ball's diameter and deviation from sphericity whose change does not depend on the influence of the machining regime is used the method of graphical approximation for time changing these indices (Figure 3).

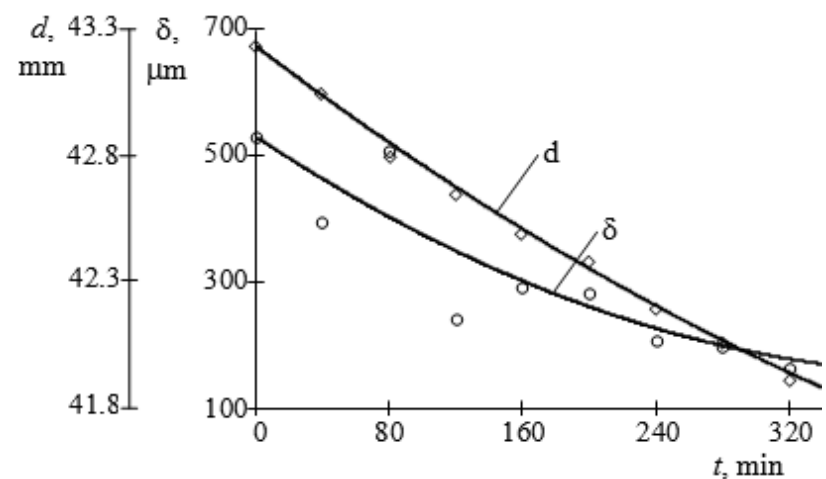

Figure 3 - Dependence of the ball diameter $d$ and the deviation from the sphericity $\delta$ from the time of grinding $t$

In Table 4 the calculated values of the rate of material removal and the rate of changing ball's shape are shown under the action only the machining regime in the 8 experiments.

Based on the results, linear models of the output variables in the normalized form are constructed taking into account the interaction of the factors:

$$
\begin{aligned}
& v_{d}=0.0488+0.6426 x_{1}-0.2113 x_{2}+0.0363 x_{3}- \\
& -0.4129 x_{1} x_{2}+0.0895 x_{1} x_{3}+0.0359 x_{2} x_{3}+0.0105 x_{1} x_{2} x_{3} \text {; } \\
& v_{\delta}=-0.0207+1.3241 x_{1}-0.6757 x_{2}-0.019 x_{3}+ \\
& +0.3691 x_{1} x_{2}-1.9998 x_{1} x_{3}+0.7676 x_{2} x_{3}-0.117 x_{1} x_{2} x_{3} \text {. }
\end{aligned}
$$


Table 4 - Matrix of changing the factors in absolute values, the value of output variables

\begin{tabular}{|c|c|c|c|c|c|c|c|c|c|}
\hline \multirow[b]{2}{*}{ Exp. no. } & \multirow{2}{*}{$\begin{array}{c}\text { Discrete } \\
\text { feeding the } \\
\text { wheel to } \\
\text { the cutting } \\
s_{w}, \mu \mathrm{m}\end{array}$} & \multirow{2}{*}{$\begin{array}{c}\text { The time of } \\
\text { grinding } \\
\text { balls between } \\
\text { feedings } \\
t_{o}, \text { min }\end{array}$} & \multirow{2}{*}{$\begin{array}{c}\text { Rotation } \\
\text { speed of } \\
\text { the table } \\
s_{t}, \mathrm{rpm}\end{array}$} & \multicolumn{3}{|c|}{$\begin{array}{l}\text { The rate of reducing the ball's } \\
\text { diameter } v_{d}, \mu \mathrm{m} / \mathrm{min}^{*}\end{array}$} & \multicolumn{3}{|c|}{$\begin{array}{l}\text { The rate of changing the ball's } \\
\text { shape } v_{\delta}, \mu \mathrm{m} / \mathrm{min}^{* *}\end{array}$} \\
\hline & & & & total & $\begin{array}{l}\text { approxi- } \\
\text { mated }\end{array}$ & $\begin{array}{c}\text { under } \\
\text { effect of } \\
\text { machining } \\
\text { regime }\end{array}$ & total & $\begin{array}{l}\text { approxi- } \\
\text { mated }\end{array}$ & $\begin{array}{c}\text { under } \\
\text { effect of } \\
\text { machining } \\
\text { regime }\end{array}$ \\
\hline 1 & 50 & 10 & 35 & 4.7 & 5.2 & -0.5 & -3.3 & -2.0 & -1.3 \\
\hline 2 & 70 & 10 & 35 & 6.2 & 4.7 & 1.5 & 2.8 & -1.5 & 4.3 \\
\hline 3 & 50 & 20 & 35 & 3.8 & 4.4 & -0.6 & -6.6 & -1.4 & -5.2 \\
\hline 4 & 70 & 20 & 35 & 3.8 & 4.2 & -0.4 & 1.2 & -1.2 & 2.4 \\
\hline 5 & 50 & 10 & 85 & 2.8 & 3.9 & -1.1 & -0.2 & -1.0 & 0.8 \\
\hline 6 & 70 & 10 & 85 & 4.8 & 3.7 & 1.1 & -1.9 & -0.9 & -1.0 \\
\hline 7 & 50 & 20 & 85 & 3.3 & 3.4 & -0.1 & -0.2 & -0.7 & 0.5 \\
\hline 8 & 70 & 20 & 85 & 3.7 & 3.2 & 0.5 & -0.9 & -0.5 & -0.4 \\
\hline
\end{tabular}

" the negative value means that the effect of machining regime leads to a decrease in productivity;

${ }^{* *}$ the negative value means that the deviation from sphericity decreases.

The statistical significance of the coefficients of the regression equations was checked by Student's criterion on the basis of the inequality

$$
t_{j}=\frac{\left|b_{j}\right|}{S\left(b_{j}\right)}>t_{p}(f),
$$

in which $S\left(b_{j}\right)=S(\bar{y}) / \sqrt{N}$ - mean square deviation of coefficients, $t_{p}(f)$ - table value of Student's criterion at $p=0.95$ for $v_{d}$, and at $p=0.80$ for $v_{\delta}$ at the number of degrees of freedom $f=N(m-1)$.
If the inequality is fairly then the coefficient differs significantly from zero.

Median deviation of regression coefficients: for medium balls $-3.2704 \cdot 10^{-2}$, for deviation from sphericity 0.4343 .

The result of checking the statistical significance of the coefficients of the regression equations in real values (Table 5): index $v_{d}-5$ statistically significant coefficients $\left(b_{1}, b_{2}, b_{4}, b_{5}\right.$ and $\left.b_{6}\right)$ from 7 , and index $v_{\delta}-4$ coefficients $\left(b_{1}, b_{2}, b_{5}\right.$ and $\left.b_{6}\right)$.

Table 5 - Calculated and tabular values of Student's criterion from checking the statistical significance of the coefficients of the regression equations

\begin{tabular}{|c|c|c|c|c|c|c|c|c|}
\hline \multicolumn{7}{|c|}{$t_{c j}=\left|b_{j}\right| / S\left(b_{j}\right)$} & \multirow{2}{*}{$\begin{array}{c}\boldsymbol{t}_{\mathrm{ctabl}} \\
\text { for } p=0.95 \\
\text { and } f=56\end{array}$} & \multirow{2}{*}{$\begin{array}{c}\boldsymbol{t}_{\mathrm{c} t a b l} \\
\text { for } p=0.80 \\
\text { and } f=56\end{array}$} \\
\hline$b_{1}$ & $b_{2}$ & $b_{3}$ & $b_{4}$ & $b_{5}$ & $b_{6}$ & $b_{7}$ & & \\
\hline \multicolumn{9}{|c|}{$v_{d}$} \\
\hline 19,8 & $-6,5$ & 1,1 & $-12,6$ & 2,7 & 9,4 & 0,3 & 2,0031 & - \\
\hline \multicolumn{9}{|c|}{$v_{\delta}$} \\
\hline 3,0 & $-1,6$ & 0,0 & 0,9 & $-4,6$ & 1,8 & $-0,3$ & - & 1,2969 \\
\hline
\end{tabular}

To verify the adequacy of the obtained regression equations according to the Fisher criterion, the variance of the adequacy of the calculation results was firstly calculated according to the model's experimental results (Table 6)

$$
S_{a d}^{2}=\frac{m}{N-l} \sum_{i=1}^{N}\left(\bar{y}_{i}-y_{j}\right)^{2},
$$

in which $y_{i}$ - the result of calculating the value of the model; $l$ - number of significant coefficients of regression equations.
Regression equations are adequate to experimental results if the condition is fulfilled

$$
F=\frac{S_{a d}^{2}}{S_{\text {frepr }}^{2}} \leq F_{1-p}\left(f_{a d}, f_{\text {repr }}\right),
$$

in which $F_{1-p}\left(f_{a d}, f_{\text {repr }}\right)$, - tabular value of Fisher's criterion at $p=0.05$ and numbers of degrees of freedom $f_{a d}=(N-l) ; f_{\text {repr }}=N(m-1)$.

Since for the obtained regression equations the above condition is satisfied by Fisher's criterion, we conclude that the regression equations are adequate for experimental results. 
Table 6 - Calculation of statistical variables for checking the adequacy of regression equations to experimental results

\begin{tabular}{|c|c|c|}
\hline Indicator & $v_{d}$ & $v_{\delta}$ \\
\hline Dispersion of reproduction $S_{\text {repr }}{ }^{2}$ & $6.8452 \cdot 10^{-2}$ & 12.0663 \\
\hline Dispersion of adequacy $S_{a d}^{2}$ & 0.0188 & 4.9500 \\
\hline Calculated Fischer's $F$-criterion $f=S_{a d}^{2} / S_{r e p r}^{2}$ & 0.669 & 0.133 \\
\hline $\begin{array}{l}\text { Tabular value of } F \text {-criterion at } p=0,05 \text { and numbers of degrees of } \\
\text { freedom } f_{a d}=(N-l), f_{\text {repr }}=N(m-1)\end{array}$ & $\begin{aligned} & 2.774 \\
\left(f_{a d}=\right. & \left.3, f_{\text {repr }}=56\right)\end{aligned}$ & $\begin{array}{c}2.536 \\
\left.f_{a d}=4, f_{\text {repr }}=56\right)\end{array}$ \\
\hline
\end{tabular}

Taking into account the results of the adequacy checking, the models of output variables in the normalized form have been constructed:

$$
\begin{aligned}
& v_{d}=0.04883+0.01071 s_{w}-0.01409 t_{o}-0.00046 s_{w} t_{o}+ \\
& +0.00002 s_{w} s_{t}+0.00034 t_{o} s_{t} \\
& v_{\delta}=-0.0207+0.0221 s_{w}-0.045 t_{o}-0.0006 s_{w} s_{t}+ \\
& +0.0009 t_{o} s_{t} .
\end{aligned}
$$$$
v_{d}=0.0488+0.6426 x_{1}-0.2113 x_{2}-0.4129 x_{1} x_{2}+
$$$$
+0.0895 x_{1} x_{3}+0.0359 x_{2} x_{3}
$$

$v_{\delta}=-0.0207+1.3241 x_{1}-0.6757 x_{2}-1.9998 x_{1} x_{3}+$ $+0.7676 x_{2} x_{3}$.

On the basis of the obtained models, graphs of function are constructed $v_{d}\left(s_{w}, t_{o}\right), v_{d}\left(s_{w}, s_{t}\right), \quad v_{d}\left(s_{t}, t_{o}\right)$ and $v_{\delta}\left(t_{o}, s_{w}\right), v_{\delta}\left(s_{t}, s_{w}\right), v_{\delta}\left(s_{t}, t_{o}\right)$ (Figures 4,5$)$.

The same models in real sizes have the form:

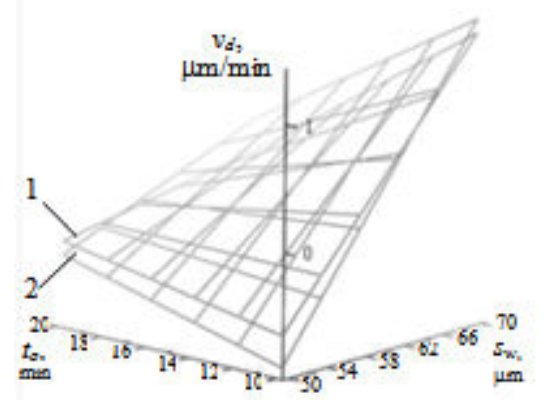

a

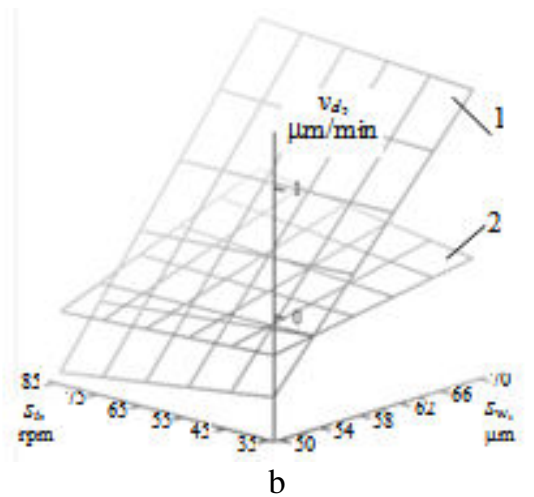

b

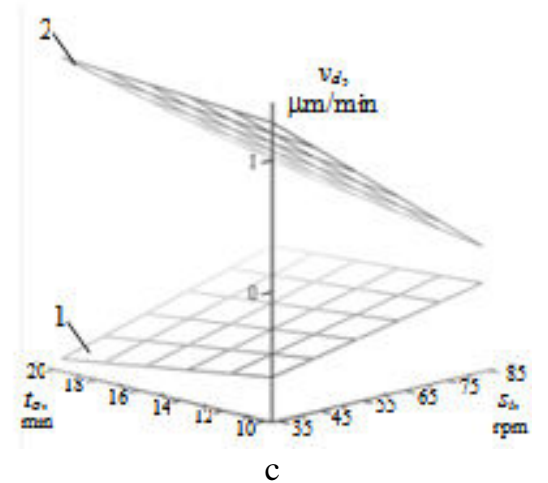

c

Figure 4 - Dependencies of the index $v_{d}$ from the value of feeding the wheel to the cutting $s_{w}$ and the time of grinding $t_{o}$ (a) at the rotation speed of the table $s_{t} 35 \mathrm{rpm}$ (1) and $85 \mathrm{rpm}(2)$; from $s_{w}$ and $s_{t}$ (b) at $t_{o} 10 \mathrm{~min}$ (1) and $20 \mathrm{~min}(2)$; from $t_{o}$ and $s_{t}(\mathrm{c})$ at $s_{w} 50(1)$ and $70 \mu \mathrm{m}(2)$

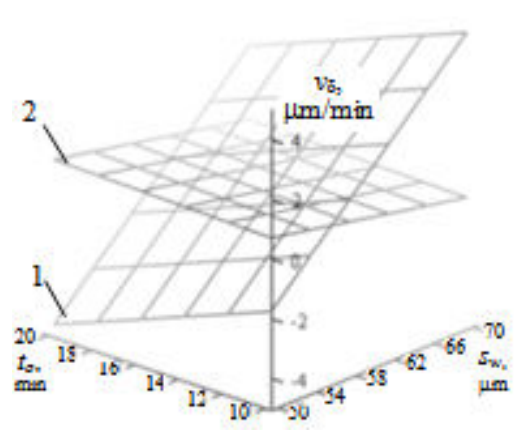

a

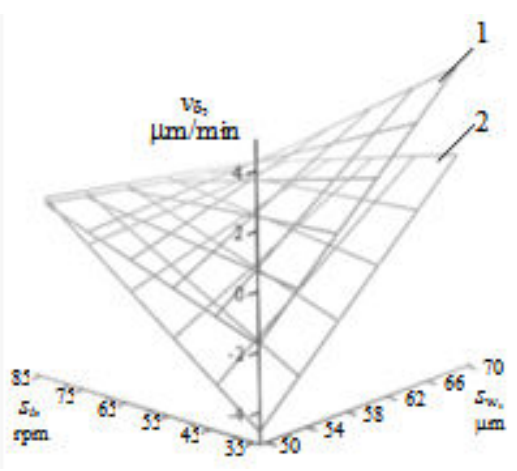

b

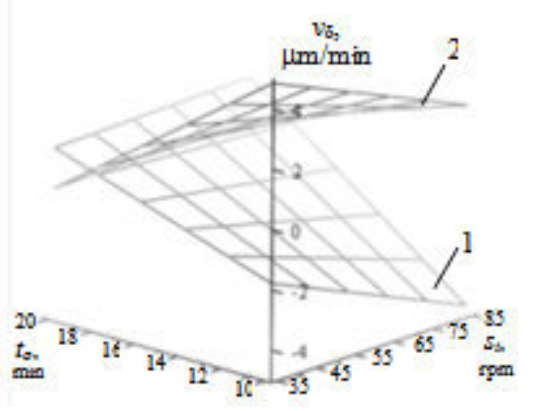

$\mathrm{C}$

Figure 5 - Dependencies of the index $v_{\delta}$ from the value of feeding the wheel to the cutting $s_{w}$ and the time of grinding $t_{o}$ (a) at the rotation speed of the table $s_{t} 35 \mathrm{rpm}$ (1) and $85 \mathrm{rpm}(2)$; from $s_{w}$ and $s_{t}$ (b) at $t_{o} 10 \mathrm{~min}$ (1) and $20 \mathrm{~min}(2)$; from $t_{o}$ and $s_{t}(\mathrm{c})$ at $s_{w} 50(1)$ and $70 \mu \mathrm{m}(2)$ 


\section{Conclusions}

As can be seen from the graphs in Figures 3 and 5, and Table 4, for the diamond grinding ceramic balls the effect of the machining regime on the rate of changing the deviation from sphericity (which estimated by the negative value of the index $v_{\delta}$ ) should be considered in two ranges of variance of deviation from sphericity. If the range is above $300 \mu \mathrm{m}$ then the effect of the machining regime is more significant. If the range is below one the effect is less significant. To reduce the deviation in the first range is possible by the simultaneous decreasing the feeding of the wheel to the cutting $s_{w}$ up to $50 \mu \mathrm{m}$ and the rotation speed of the table $s_{t}$ up to $35 \mathrm{rpm}$ with increasing the time of grinding $t_{o}$ up to $20 \mathrm{~min}$. This machining regime will ensure changing $v_{\delta}$ in the range from -1.3 to $-5.2 \mu \mathrm{m} / \mathrm{min}$. In the second range, on the contrary, the simultaneous increase of the specified parameters within the studied range will be effective at increasing $s_{w}$ up to
$70 \mu \mathrm{m}$ and $s_{t}$ up to $85 \mathrm{rpm}$ and decreasing $t_{o}$ up to $10 \mathrm{~min}$, that will provide changing $v_{\delta}$ in the range from -0.4 to $-1.0 \mu \mathrm{m} / \mathrm{min}$.

At the same time, the growth of the productivity (which estimated by increasing the index $v_{d}$ ) should be expected at increasing the feeding of the wheel to the cutting $s_{w}$ within the studied range, so long as the rotation speed of the table $s_{t}$ and the time of grinding $t_{o}$ are reduced (Figure 3, 4, and Table 4). Since the strategic goal of the diamond grinding ceramic balls is primarily to achieve the maximum possible rate of decreasing the deviation from the sphericity and only in the second place the acceptable process productivity, the current value of this deviation should be taken into account. Depending on it, it is also necessary to choose the recommendations for choice of the machining regime: more the deviation from sphericity - lower the machining parameters so long as the time of grinding between the feedings increases, and vice versa.

\section{References}

1. Hybrid Ball Bearings. Retrieved from: https://www.bearingworks.com/products/hybrid-ball-bearings.php.

2. Sverhtverdye materialy. Poluchenie e izmerenija. Almazno-abrazivnyy instrument v tekhnolohijah mekhanoobrabotki (2007). Kyiv, Alkon [in Russian].

3. Pasichnyy, O. O. (2002). Pidvytshennja efektyvnosti pretsezeonnoji almaznoji obrobky detaley typu , kulia” z konstruktsijnoji keramiky. Thesis for the Ph.D. degree. Kyiv, Bakul Institute for Superhard Materials of NAS [in Ukrainian].

4. Feng, M., Wu, Y., Yuan, \& J., Ping, Z. (2017). Processing of high-precision ceramic balls with a spiral V-groove plate. Front. Mech. Eng. 2017, 12 (1), 132-142.

5. Zhou, F., Yuan, J., Lyu, B., et al. (2016). Kinematics and trajectory in processing precision balls with eccentric plate and variable-radius V-groove. The International Journal of Advanced Manufacturing Technology, 2016, 84 (9), 2167-2178.

6. Ma, W. (2013). High efficiency ultra-precision grinding of ceramic balls. Dissertation for the Doctoral Degree. Saga, Saga University.

7. Filatov, Y. D., Vetrov, A. H., Sidorko, V. I., Filatov, A. Yu., \& Kovalev S. V. (2013). Zakonomernosti finishnoy almaznoabrazivnoy obrabotki monokristallicheskoho karbida kremnija. Superhard Materials, No 5, pp. 63-71 [in Russian].

8. Filatov, Y. D., Vetrov, A. H., Sidorko, V. I., et al. (2015). Polirovanije elementov optiko-elektronnoy tekhniki iz monokristallicheskoho karbida kremnija. Superhard Materials, No 1, pp. 63-71 [in Ruissian].

9. Filatov, Y. D., Filatov, O. Yu., Monteil, G., Heisel, U., \& Storchak, M. (2010). Bound-abrasive grinding and polishing of surfaces of optical materials. Proc. of SPIE, Vol. 7786, Art. no.778613.

10. Husev, V. V., \& Kalafatova, L. N. (2012). Tekhnolohicheskoje obespechenije kachestva obrabotki izdeliy iz tekhnicheskoy keramiki. Donetsk, DonNTU [in Russian].

11. Filatov, Y. D., \& Rohov, V. V. (1994). Klasternaja model mekhanizma ustalostnoho iznosa $\mathrm{SiO}_{2}$-sodergatshih materialov pri ikh polirovanii instrumentom so svjazannym polirovalnym poroshkom na osnove dioksida tserija. Chapter 1. Superhard Materials, No. 3, pp. 40-43 [in Russian].

12. Filatov, Y. D. (1991). Mekhanizm obrazovanija mikroreljefa poverkhnosti pri obrabotke stekla. Tam ge., No. 5, pp. 61-65.

13. Morozov, E. M., Zernin, M. V. (1999). Kontaktnye zadachi mekhaniki razrushenija. Moscow, Mashinostroyeniye [in Russian].

14. Kulich, V. H., Kushch, V. I., Tkach, V. N., Maystrenko, A. L. (2009). K voprosu o vozmognostjakh poluchenija vysokoplotnykh keramicheskikh izdeliy na osnove samosvjazannoho karbida kremnija. Superhard Materials, No. 1, pp. 18-35 [in Russian].

15. Proverka znachimosti koeffitsientov i adelvatnosti uravnenija regressii, poluchennykh pri obrabotke rezultatov PFE 22 i 23 . Retrieved from: https://politeh24.com/4207\#more-4207 [in Russian]. 


\section{Алмазне шліфування керамічних куль 3 карбіду кремнію}

Сохань С. В., Майстренко А.Л., Кулич В. Г., Сороченко В. Г., Возний В. В., Гаманюк М. П., Зубанєв Є. М. Інститут надтвердих матеріалів ім. В. М. Бакуля НАН України, вул. Автозаводська, 2, м. Київ, 04074, Україна

Анотація. Досліджено експериментально вплив режиму обробки на показники процесу алмазного шліфування керамічних куль 3 карбіду кремнію: швидкість знімання припуску i швидкість зменшення/збільшення відхилення від сферичності поверхні куль. Запропоновано методику виокремлення 3 цих показників частки, обумовленої власне впливом режиму обробки. Для цього застосовано метод графічної апроксимації змінювання у часі діаметру кулі і відхилення від сферичності. Встановлено, що виокремлені частки показників процесу можуть змінюватися як у бік зростання, так і бік зниження в залежності від значень параметрів режиму обробки, як-от: дискретної подачі алмазного круга на врізання, частоти подачі круга і швидкості обертання стола 3 кулями. Як метод подальшого визначення впливу режиму обробки обрано повний факторний експеримент типу 23, в якому факторами були вказані вище параметри режиму обробки. Знайдено найбільш ефективне для зменшення відхилення від сферичності поверхні куль поєднання цих параметрів.

Ключові слова: керамічні кулі з карбіду кремнію, алмазне шліфування, параметри режиму обробки, швидкість знімання припуску і швидкість змінювання форми поверхні куль. 